\title{
Diagnosis of the current situation of the cadastre and its relationship with systematic topographic mapping
}

\author{
Andrea Lopes Iescheck ${ }^{\mathrm{a},}$ *, Claudia Robbi Sluter ${ }^{\mathrm{a}}$, Andrea Flávia Tenório Carneiro ${ }^{\mathrm{b}}$, Daniele \\ Regina Pontes c ${ }^{\text {, José Antônio Peres Gediel }}{ }^{\text {d }}$ \\ ${ }^{a}$ Federal University of Rio Grande do Sul,Department of Geodesy, andrea.iescheck@ufrgs.br, robbi.sluter@ufrgs.br \\ ${ }^{b}$ Federal University of Pernambuco, Department of Cartographic Engineering, andreaftenorio@gmail.com \\ ${ }^{c}$ Federal University of Parana, Department of Geomatics, danielepontes.ufpr@gmail.com \\ ${ }^{d}$ Federal University of Parana, Department of Private and Procedural Law, jagediel@gmail.com \\ * Corresponding author
}

Keywords: Cadastre, Topographic map, Land legislation

\begin{abstract}
:
The discussion and the questions formulated in this research are related to the need to integrate topographic mapping and cadastre and the diagnosis of the current situation concerning cadastre and its relationship with the topographic mapping. Topographic mapping is the spatial reference for any activity in a society focused on territory planning, use, and occupation. In turn, the territorial cadastre describes the relationship between people and land, serving as a basis for land and land use management, including territorial planning, and supporting sustainable development and environmental protection. Therefore, an efficient cadastre relies on mapping the spatial units' boundaries according to their legal situation, confirming the interdependence between these systems. Brazil has never had a complete, updated topographic mapping on the scales necessary for implementing a territorial cadastre to support land policies and adequately meet the legal standards on territorial issues. Currently, the available mapping corresponds to 5\% of the Brazilian territory on the scale of $1: 25,000$ and $24 \%$ on the scale of 1:50,000, which is insufficient to support the territorial cadastre and apply the legislation on territorial planning.
\end{abstract}

The cadastre's function is collecting and making available graphic and descriptive information about the parcels of territory, based on the survey of its limits. In Brazil, the absence of national registration law and an institution whose primary competence is to establish guidelines for its elaboration has meant that it has developed without integration between rural and urban cadastres. Federal law n ${ }^{\circ} 5868 / 72$ established the rural cadastre (National Rural Cadastre System) under the federal administrations' responsibility. On the other hand, there is no specific legislation for urban cadastre. Its implementation is done by the municipality, generally for tax purposes. Over time, rural cadastres were based exclusively on descriptive information since there is no systematic mapping on an adequate scale to support it. Also, topographic mapping is not an essential element of a rural cadastre in Brazil. Table 1 summarizes the current constitution of the leading rural cadastres. In addition to these, there are also environmental, indigenous land, and federal land cadastres (which include urban properties).

\begin{tabular}{|l|l|l|l|}
\hline & SNCR & CAFIR & CNIR \\
\hline Administration & $\begin{array}{l}\text { National Institute of } \\
\text { Colonization and } \\
\text { Agrarian Reform } \\
\text { (INCRA) }\end{array}$ & $\begin{array}{l}\text { Internal } \\
\text { Revenue } \\
\text { Service (IRS) }\end{array}$ & INCRA + IRS \\
\hline Descriptive data & Yes & Yes & $\begin{array}{l}\text { Yes (in a phase of compatibility between the SNCR } \\
\text { and CAFIR) }\end{array}$ \\
\hline Topographic mapping related & No & No & \multicolumn{1}{c|}{ No } \\
\hline $\begin{array}{l}\text { Geometric base (the } \\
\text { measurement of parcels) }\end{array}$ & No & No & $\begin{array}{l}\text { Possibility of using georeferenced surveys in response } \\
\text { to Federal Law 10.267/2001 }\end{array}$ \\
\hline
\end{tabular}

Table 1 - Current constitution of the leading rural cadastres in Brazil - SNCR - National System of Rural Properties; CAFIR -Cadastre of Rural Properties, and CNIR - National Cadastre of Urban Properties.

Most municipalities follow the methodology of the CIATA Project for urban cadastre. The Secretariat of Economic and Finance of the Ministry of Treasury of Brazil implemented this project as an experiment around 1973 with resources from the Federal Data Processing Service - SERPRO. In general, the methodology used by the CIATA Project for the urban properties cadastre was composed of two phases: Execution and Implementation. The execution phase consisted of 6 stages: Sectorization of Inspection, Cadastral Survey, Property Valuation, Information Treatment, Launch, and Final Plan, with the first four stages being performed directly by SERPRO and the last two by the municipality. 
With a methodology consistent with the technology available at the time, the CIATA Project envisaged the development of isolated cadastre plans, whose location in the municipal urban perimeter was identified in a Cadastral Reference Plan. The municipalities could not elaborate on the expected topographic mapping since there are no topographic maps, so many had an exclusively descriptive registration based on information obtained from the cadastral information bulletins. The municipalities with better technical and economic conditions developed cadastres based on the photogrammetric mapping that is not integrated into the official topographic mapping. Also, the current cadastres reflect the social inequalities of a vast territorial country. Few structured cadastres are available to serve multiple purposes. Some municipalities seek to apply new technologies to implement simpler cartographic bases, which meet fiscal objectives, and others do not yet have cadastral plans to improve their cadastral systems. Once again, the lack of topographic mapping on a scale compatible with the urban cadastre makes it challenging, or even impossible, to implement a cadastre that serves as a basis for developing integrated public policies.

As planned and performed in France by Colbert and Cassini, the topographic mapping must be carried out with a Geodetic Reference System, such as the Brazilian Geodetic System (BGS) materialized in geodetic benchmarks. The set of geodetic landmarks must be connected to a network. Consequently, the network conformation and the mathematical connection between all geodetic landmarks guarantee the uniformity of the positional quality in the mapped territory. The uniformity and homogeneity of the geodesic network make it possible to map large scales with high accuracy and precision. This fact is one of the significant advances that Cassini's Map of France provided for topographic mappings, allowing the territorial cadastre to be with uniform positional quality throughout the national territory.

When the land cadastre is carried out with local surveys, even when linked to the BGS, with independent results particular to each location, there is a set of surveys throughout the country geometrically independent cadastral representations. By allowing colloquial language, one can imagine the various cadastres in different regions as a "patchwork quilt." These "patches" are represented at different levels of detail and positional quality. However, there must be interdependence between the cadastre and topographic mapping. It should be expected that the homogeneity in the land cadastre standards should be achieved throughout the national territory.

Colonization created the founding elements of tensions that would lead to an immense territory dispute. The land disputes find deep marks in the colonization period, which still can be noticed in land occupation situations. In effect, knowledge about the land, territories, environments, and peoples is meaningful in the constitution of powers, the construction of policies, interpreting society, and the intervention of reality. In Brazil, the bases for the constitution of systems, often imprecise and unrealistic, were forged into legitimacy. We found that somehow, given the general situation since colonization, it was urgent to establish the general land administration system. Given the need to produce official documents, a registration system was prescribed, featuring topographic mapping and surveying. However, it was only in the 20th century that attempts at territorial planning and the structuring of systems and cadastres took place, along with the legal formulation of territorial ordering that went beyond the mere protection of private territorial interests.

Our future research challenges are related to the incorporation of complexities and absences in legal-cartographiccadastral issues, proposing suitable solutions for:

(i) What are the consequences of the absence of topographic and cadastral mapping for Brazilian society?

(ii) Does the cadastre in Brazil assure the rights, restrictions, and responsibilities towards people and land?

(iii) How to make it possible to build a cadastre system that can assure the rights, restrictions, and responsibilities of the relationship between people and land?

We published this paper in the Brasilian Journal of Cartography. 